Article

\title{
Increased Carbon Dioxide Concentration Improves the Antioxidative Properties of the Malaysian Herb Kacip Fatimah (Labisia pumila Blume)
}

\author{
Mohd Hafiz Ibrahim and Hawa Z.E. Jaafar * \\ Department of Crop Science, Faculty of Agriculture, University Putra Malaysia, Serdang 43400, \\ Selangor, Malaysia; E-Mail: mhafizphd@gmail.com (M.H.I.) \\ * Author to whom correspondence should be addressed; E-Mail: hawazej@gmail.com; or \\ hawazej@agri.upm.edu.my; Tel.: +6-03-8946-6922 / +6-012-372-3585; Fax: +6-03-8943-5973.
}

Received: 24 May 2011; in revised form: 30 June 2011 / Accepted: 30 June 2011 /

Published: 20 July 2011

\begin{abstract}
A randomized complete randomized design (RCBD) 3 by 3 experiment was designed to investigate and distinguish the relationships among production of secondary metabolites (total phenolics, TP; total flavonoids, TF), gluthatione (GSH), oxidized gluthatione (GSSG), soluble carbohydrate and antioxidant activities of the Malaysian medicinal herb Labisia pumila Blume under three levels of $\mathrm{CO}_{2}$ enrichment $(400,800$ and $1,200 \mu \mathrm{mol} \mathrm{mol}{ }^{-1}$ ) for 15 weeks. It was found that the treatment effects were solely contributed by interaction of $\mathrm{CO}_{2}$ levels and secondary metabolites distribution in plant parts, GSH, GSHH and antioxidant activities (peroxyl radicals (ROO), superoxide radicals $\left(\mathrm{O}_{2}\right)$, hydrogen peroxide $\left(\mathrm{H}_{2} \mathrm{O}_{2}\right)$ and hydroxyl radicals $(\mathrm{OH})$. The records of secondary metabolites, glutahione, oxidized gluthathione and antioxidant activities in a descending manner came from the leaf enriched with $1,200 \mu \mathrm{mol} / \mathrm{mol} \mathrm{CO} \mathrm{CO}_{2}>$ leaf $800 \mu \mathrm{mol} / \mathrm{mol} \mathrm{CO}_{2}>$ leaf $400 \mu \mathrm{mol} / \mathrm{mol} \mathrm{CO}_{2}>$ stem $1,200 \mu \mathrm{mol} / \mathrm{mol} \mathrm{CO}_{2}>$ stem $800 \mu \mathrm{mol} / \mathrm{mol} \mathrm{CO}_{2}>$ stem $400 \mu \mathrm{mol} / \mathrm{mol} \mathrm{CO}_{2}>\operatorname{root} 1,200 \mu \mathrm{mol} / \mathrm{mol} \mathrm{CO} \mathrm{CO}_{2}>\operatorname{root} 800 \mu \mathrm{mol} / \mathrm{mol} \mathrm{CO}_{2}>\operatorname{root}$ $400 \mu \mathrm{mol} / \mathrm{mol} \mathrm{CO}_{2}$. Correlation analyses revealed strong significant positive coefficients of antioxidant activities with total phenolics, flavonoids, GSH and GSHH indicating that an increase in antioxidative activity of $L$. pumila under elevated $\mathrm{CO}_{2}$ might be up-regulated by the increase in production of total phenolics, total flavonoids, GSH, GSHH and soluble sugar. This study implied that the medicinal potential of herbal plant such as L. pumila can be enhanced under elevated $\mathrm{CO}_{2}$, which had simultaneously improved the antioxidative
\end{abstract}


activity that indicated by the high oxygen radical absorbance activity against $\mathrm{ROO}, \mathrm{O}_{2}$, $\mathrm{H}_{2} \mathrm{O}_{2}$, and $\mathrm{OH}$ radicals.

Keywords: elevated $\mathrm{CO}_{2}$; secondary metabolites; soluble carbohydrate; gluthatione; antioxidative properties

\section{Introduction}

Carbon dioxide is one of the most limiting factors in photosynthesis. The possibility of improving photosynthesis in crops through $\mathrm{CO}_{2}$ enrichment has interested agriculturists for many years [1]. $\mathrm{CO}_{2}$ enrichment has been shown to increase plant growth, development, and yield of agricultural crops, and this response is a function of $\mathrm{CO}_{2}$ concentration and duration [2,3]. Elevated $\mathrm{CO}_{2}$ concentrations enhanced vegetative growth, biomass increment, carbohydrate accumulation, fruit productivity, and quality in plants under glass-house conditions [4]. Crops under enriched $\mathrm{CO}_{2}$ atmosphere acquire positive features with enhanced plant adaptation and growth. The greatest advantages of $\mathrm{CO}_{2}$ enrichment is in the enhancement of photosynthetic capacity, particularly under adverse climatic conditions and this would become most apparent in the vegetative growth of young plants $[5,6]$.

The antioxidant properties in food have been a focus of interest in recent years due to the health maintenance functions of these components that can help reduce the risk of chronic diseases such as cancer, hypertension and diabetes. This is attributed to the high scavenging activity of antioxidants towards free radicals that are usually associated with these diseases [7,8]. It is currently known that phenolic acids and flavonoids are antioxidants with high anti-inflammatory and anticarcinogenic activities [7,9,10]. It is also known that phenolics and flavonoids can function as free radical scavengers, reducing agents and quenchers of singlet oxygen formation [11]. The components of polyphenols have been proven to have important roles in the regulation of cancer and disease development in the human body $[12,13]$. For instance, in green tea the effectiveness of the plant extract to inhibit cancer and tumor invasion is due to the high phenolics and flavonoids content in the plant [14].

Rising levels of atmospheric $\mathrm{CO}_{2}$ can alter plant growth and the partitioning of secondary metabolites [8]. An increase in C-based secondary metabolites frequently occurs when environmental conditions promote the accumulation of non-structural carbohydrates (TNC) in plants. Elevated atmospheric $\mathrm{CO}_{2}$ concentrations often increase TNC concentrations in plants and thus possibly stimulate secondary metabolism [15]. Idso et al. [16] evaluated the response of the tropical spider lily (Hymenocallis littoralis) to elevated levels of atmospheric $\mathrm{CO}_{2}$ over four growing seasons and found that a $75 \%$ increase in the air's $\mathrm{CO}_{2}$ concentration produced an $8 \%$ increase in pancratistatin, an $8 \%$ increase in trans-dihydronarciclasine, and a $28 \%$ increase in narciclasine that are effective against lymphocytic leukemia and ovary sarcoma [17]. In the early studies of Barbale [18] and Madsen [19,20], a tripling of the atmospheric $\mathrm{CO}_{2}$ concentration produced a modest (7\%) increase in antioxidant activity in the leaves and fruits of tomato plants. Tajiri [21] and Schwanz et al. [22] found ascorbate concentrations in the sun leaves of sour orange trees to be significantly enhanced by a $600 \mu \mathrm{mol} / \mathrm{mol}$ $\mathrm{CO}_{2}$ increase in the air. It can be concluded that exposure of plant to high levels of $\mathrm{CO}_{2}$ can increase the production of secondary metabolites and antioxidant activity. 
Rao et al. [23] observed that atmospheric $\mathrm{CO}_{2}$ enrichment increases NADPH content and leads to the maintenance of higher activities of antioxidant enzymes such as glutathione reductase. Since this enzyme is primarily responsible for the high redox states of both glutathione and ascorbate [24], this phenomenon may well be operative among a host of antioxidants, and especially among vitamins. It is interesting to note, however, that several studies that have looked at the effects of atmospheric $\mathrm{CO}_{2}$ enrichment on plant antioxidative compounds have found increased concentrations of these plant constituents as well as increase in activity against peroxyl radicals (ROO), superoxide radicals $\left(\mathrm{O}_{2}\right)$, hydrogen peroxide $\left(\mathrm{H}_{2} \mathrm{O}_{2}\right)$ and hydroxyl radicals $(\mathrm{OH})$ [25]. Exposing medicinal plants to $\mathrm{CO}_{2}$ may give positive response to increased antioxidative properties. Contrastingly, several researchers have found reduction in antioxidative activity under elevated $\mathrm{CO}_{2}$ exposure [26-29] probably due to differences in plant species responses and other interacting microenvironment.

Labisia pumila is good source of natural antioxidants [30]. In addition, the plant is also rich in anthocyanins, flavonoids, and phenolic acids [31,32]. Results of elevated $\mathrm{CO}_{2}$ exposure on total phenolics and flavonoids have been reported by Ibrahim et al. [33], however, there is no available information on the effect of $\mathrm{CO}_{2}$ concentration on the production of secondary metabolites and scavenging capacity against active oxygen species for this plant species. Hence, this study was performed to evaluate the effects of elevated carbon dioxide enrichment on the concentration of phenolics, flavonoids, glutathione (GSH), gluthatione oxidase (GSSG) and antioxidative activity in the ethanolic extracts of L. pumila. The relationships among parameters of total phenolics, flavonoids, gluthatione, glutatione oxidase and antioxidative activity [peroxyl radicals (ROO), superoxide radicals $\left(\mathrm{O}_{2}\right)$, hydrogen peroxide $\left(\mathrm{H}_{2} \mathrm{O}_{2}\right)$ and hydroxyl radicals $(\mathrm{OH} \cdot)$ ] were also established.

\section{Results and Discussion}

\subsection{Total Phenolics and Flavonoids Profiling}

Accumulation of total phenolics and flavonoids in L. pumila was influenced by the interaction effect between $\mathrm{CO}_{2}$ and plant parts $(\mathrm{P} \leq 0.01$; Table 1$)$. Generally, total phenolics was observed to be higher in the leaf at $1,200 \mu \mathrm{mol} / \mathrm{mol} \mathrm{CO} 2(1.259 \mathrm{mg}$ gallic acid $/ \mathrm{g}$ dry weight $)$ followed by leaf $-800 \mu \mathrm{mol} / \mathrm{mol}$ $\mathrm{CO}_{2}(1.167 \mathrm{mg}$ gallic acid/g dry weight $)$, leaf $-400 \mu \mathrm{mol} / \mathrm{mol} \mathrm{CO} 2(0.835 \mathrm{mg}$ gallic acid/g dry weight $)$, stem-1,200 $\mu \mathrm{mol} / \mathrm{mol} \mathrm{CO}_{2}(0.862 \mathrm{mg}$ gallic acid $/ \mathrm{g}$ dry weight $)$, stem-800 $\mu \mathrm{mol} / \mathrm{mol} \mathrm{CO}_{2}(0.678 \mathrm{mg}$ gallic acid/g dry weight), stem- $400 \mu \mathrm{mol} / \mathrm{mol} \mathrm{CO}_{2}(0.531 \mathrm{mg}$ gallic acid/g dry weight), root-1,200 $\mu \mathrm{mol} / \mathrm{mol} \mathrm{CO} 2(0.554 \mathrm{mg}$ gallic acid $/ \mathrm{g}$ dry weight $)$, root $-800 \mu \mathrm{mol} / \mathrm{mol} \mathrm{CO} \mathrm{CO}_{2}(0.343 \mathrm{mg}$ gallic acid $/ \mathrm{g}$ dry weight $)$ and root- $400 \mu \mathrm{mol} / \mathrm{mol} \mathrm{CO} 2(0.311 \mathrm{mg}$ gallic acid $/ \mathrm{g}$ dry weight $)$. Total flavonoids content followed the same trend with total phenolics where the highest total flavonoids was observed in leaf at $1,200 \mu \mathrm{mol} / \mathrm{mol} \mathrm{CO}$ that registered $0.276 \mathrm{mg}$ rutin/g dry weight and the lowest was in the root at $400 \mu \mathrm{mol} / \mathrm{mol} \mathrm{CO}_{2}$ that contained only $0.052 \mathrm{mg}$ rutin/g dry weight. The present results are in agreement with those from Norhaiza et al. [30] and Karimi et al. [34] where they found the highest bioactive compound (total phenolics and flavonoid) of L. pumila was highest accumulated in the leaf than other plant parts. Furthermore, from previous study by Ibrahim et al. [33] it was shown that the enrichment of L. pumila to elevated $\mathrm{CO}_{2}$ was able to enhance the production of total phenolics and flavonoids content, especially in the leaves compared to other plant parts. In this study it was shown 
that the increased production of secondary metabolites was due to an increase in the production of total non- structural carbohydrate (TNC) that up-regulated the production of secondary metabolites. The enhanced production of plant secondary metabolites under high levels of $\mathrm{CO}_{2}$ have also been observed in Zingiber officianale, Betula pendula and Fragaria annassa [25,35,36]. The present result indicated that enrichment of L. pumila with high $\mathrm{CO}_{2}$ can up-regulate the production of secondary metabolites. The high total phenolics and flavonoids content in the plant has been shown to have anticancer properties and also have an application to use as antibiotics, antidiarrhea, antiulcer and antiinflammatory agents, as well as in the treatment of diseases such as hypertension, vascular fragility, allergies and hyperchlolestrolemia [37,39].

Table 1. Total phenolics and flavonoids contents in different parts of L. pumila under different $\mathrm{CO}_{2}$ concentration.

\begin{tabular}{|c|c|c|c|}
\hline $\begin{array}{c}\mathrm{CO}_{2} \text { levels } \\
(\mu \mathrm{mol} / \mathrm{mol})\end{array}$ & Plant parts & $\begin{array}{c}\text { Total phenolics } \\
\text { (mg/g gallic acid dry } \\
\text { weight) }\end{array}$ & $\begin{array}{c}\text { Total flavonoid } \\
\text { (mg/g rutin dry } \\
\text { weight) }\end{array}$ \\
\hline \multirow{3}{*}{400} & Leaf & $0.835 \pm 0.017 b$ & $0.111 \pm 0.018 \mathrm{c}$ \\
\hline & Stem & $0.531 \pm 0.022 \mathrm{~d}$ & $0.071 \pm 0.022 \mathrm{~d}$ \\
\hline & Root & $0.311 \pm 0.018 \mathrm{e}$ & $0.052 \pm 0.032 \mathrm{~d}$ \\
\hline \multirow{3}{*}{800} & Leaf & $1.167 \pm 0.023 \mathrm{a}$ & $0.247 \pm 0.017 \mathrm{a}$ \\
\hline & Stem & $0.678 \pm 0.021 \mathrm{c}$ & $0.143 \pm 0.023 b$ \\
\hline & Root & $0.343 \pm 0.011 \mathrm{c}$ & $0.067 \pm 0.024 d$ \\
\hline \multirow{3}{*}{1200} & Leaf & $1.259 \pm 0.032 \mathrm{a}$ & $0.276 \pm 0.021 \mathrm{a}$ \\
\hline & Stem & $0.862 \pm 0.027 b$ & $0.165 \pm 0.032 b$ \\
\hline & Root & $0.554 \pm 0.041 \mathrm{~d}$ & $0.085 \pm 0.031 \mathrm{~d}$ \\
\hline
\end{tabular}

All analyses are mean \pm standard error of mean (SEM), $N=18$. Means not sharing a common single letter were significantly different at $\mathrm{P} \leq 0.05$.

\subsection{Antioxidant Activity against Peroxyl Radicals (ROO), Superoxide Radicals $\left(\mathrm{O}_{2}\right)$, Hydrogen} Peroxide $\left(\mathrm{H}_{2} \mathrm{O}_{2}\right)$ and Hydroxyl Radicals $(\mathrm{OH})$

The antioxidant activity of $\mathrm{ROO}, \mathrm{O}_{2}, \mathrm{H}_{2} \mathrm{O}_{2}$ and $\mathrm{OH}$ was influenced by the interaction effects between $\mathrm{CO}_{2}$ and plant parts $(\mathrm{P} \leq 0.01$; Table 2$)$. In $\mathrm{ROO}$ the highest antioxidant activity was recorded in the leaf at $1,200 \mu \mathrm{mol} / \mathrm{mol} \mathrm{CO} 2(145.67 \mu \mathrm{mol} \mathrm{TE} / \mathrm{g}$ dry weight $)$ followed by leaf $-800 \mu \mathrm{mol} / \mathrm{mol} \mathrm{CO}_{2}$ (142.32 $\mu \mathrm{mol} \mathrm{TE} / \mathrm{g}$ dry weight), leaf-400 $\mu \mathrm{mol} / \mathrm{mol} \mathrm{CO}_{2}(132.61 \mu \mathrm{mol} \mathrm{TE} / \mathrm{g}$ dry weight), stem-1,200 $\mu \mathrm{mol} / \mathrm{mol} \mathrm{CO} 2\left(121.21 \mu \mathrm{mol} \mathrm{TE} / \mathrm{g}\right.$ dry weight), stem-800 $\mu \mathrm{mol} / \mathrm{mol} \mathrm{CO} \mathrm{CO}_{2}(142.32 \mu \mathrm{mol} \mathrm{TE} / \mathrm{g}$ dry weight), stem- $400 \mu \mathrm{mol} / \mathrm{mol} \mathrm{CO} 2(100.31 \mu \mathrm{mol} \mathrm{TE} / \mathrm{g}$ dry weight), and in the root at $400 \mu \mathrm{mol} / \mathrm{mol}$ $\mathrm{CO}_{2}\left(94.32 \mu \mathrm{mol} \mathrm{TE} / \mathrm{g}\right.$ dry weight). For $\mathrm{O}_{2}, \mathrm{H}_{2} \mathrm{O}_{2}$ and $\mathrm{OH}$, the antioxidant activity showed similar pattern as ROO. In $\mathrm{OH}$ antioxidant, the highest activity was recorded in the leaf at $1,200 \mu \mathrm{mol} / \mathrm{mol}$ $\mathrm{CO}_{2}\left(66.54 \mu \mathrm{mol}\right.$ chlorogenic acid/g dry weight) and the lowest was in root at $400 \mathrm{~mol} / \mathrm{mol} \mathrm{CO}_{2}$ that only recorded $18.65 \mu \mathrm{mol}$ chlorogenic acid/g dry weight. In this study, elevation of $\mathrm{CO}_{2}$ over 800 to $1,200 \mu \mathrm{mol} / \mathrm{mol} \mathrm{CO}_{2}$ all resulted in an increase in values of oxygen radical absorbance capacity. The highest $\mathrm{CO}_{2}$ enrichment $\left(1,200 \mu \mathrm{mol} / \mathrm{mol} \mathrm{CO}_{2}\right)$ yielded $L$. pumila plants with the most ROO, as well as $\mathrm{O}_{2}, \mathrm{H}_{2} \mathrm{O}_{2}, \mathrm{OH}$ absorbance capacity. This data indicated that $L$. pumila grown with $\mathrm{CO}_{2}$ enrichment had 
high scavenging activity for chemically generated active oxygen species [25]. Correlation analyses in Table 3 show that the increase in antioxidative properties might be up-regulated by the increase in total phenolics and flavonoids content of plant under elevated $\mathrm{CO}_{2}$. All the antioxidant properties were observed to have strong significant positive correlations with total phenolics and flavonoids. This imply that the increase in total phenolics and flavonoids under elevated $\mathrm{CO}_{2}$ might be associated with increased antioxidant capacities that may allow quenching of the excited state of active oxygen species $[39,40]$.

Table 2. Antioxidant activity against Peroxyl Radicals (ROO), Superoxide Radicals $\left(\mathrm{O}_{2}\right)$, Hydrogen Peroxide $\left(\mathrm{H}_{2} \mathrm{O}_{2}\right)$ and Hydoxyl Radicals in different part of L. pumila under different $\mathrm{CO}_{2}$ concentration.

\begin{tabular}{|c|c|c|c|c|c|}
\hline $\begin{array}{c}\mathrm{CO}_{2} \text { levels } \\
\left(\mu \mathrm{mol} \mathrm{mol}{ }^{-1}\right)\end{array}$ & $\begin{array}{l}\text { Plants } \\
\text { Parts }\end{array}$ & $\begin{array}{c}\text { ROO } \\
(\mu \mathrm{mol} \mathrm{TE} / \mathrm{g} \\
{\operatorname{dry~wt})^{\mathrm{a}}}^{\mathrm{d}}\end{array}$ & $\begin{array}{c}\mathrm{O}_{2}(\mu \mathrm{mol} \\
\alpha \text {-tocopherol } / \mathrm{g} \\
\text { dry wt })^{b}\end{array}$ & $\begin{array}{c}\mathrm{H}_{2} \mathrm{O}_{2}(\mu \mathrm{mol} \\
\operatorname{ascorbate} / \mathrm{g} \\
\text { dry wt) }\end{array}$ & $\begin{array}{c}\text { OH ( } \mu \text { mol } \\
\text { chlorogenic acid/g } \\
\text { dry wt) }\end{array}$ \\
\hline \multirow{3}{*}{400} & Leaf & $132.61 \pm 6.4 \mathrm{a}$ & $39.22 \pm 0.7 b$ & $19.45 \pm 0.5 \mathrm{a}$ & $43.22 \pm 2.7 b$ \\
\hline & Stem & $100.31 \pm 5.3 \mathrm{c}$ & $27.43 \pm 0.5 c$ & $12.32 \pm 0.1 \mathrm{c}$ & $33.21 \pm 3.2 \mathrm{c}$ \\
\hline & Root & $94.32 \pm 4.2 \mathrm{~d}$ & $18.91 \pm 1.6 \mathrm{e}$ & $9.23 \pm 0.3 \mathrm{e}$ & $18.65 \pm 1.9 \mathrm{~d}$ \\
\hline \multirow{3}{*}{800} & Leaf & $142.32 \pm 3.4 \mathrm{a}$ & $44.56 \pm 2.3 \mathrm{a}$ & $23.34 \pm 0.2 \mathrm{a}$ & $56.73 \pm 4.2 \mathrm{a}$ \\
\hline & Stem & $112.32 \pm 2.3 \mathrm{c}$ & $32.12 \pm 1.7 \mathrm{c}$ & $15.43 \pm 0.1 b$ & $40.12 \pm 5.6 b$ \\
\hline & Root & $87.34 \pm 1.7 \mathrm{~d}$ & $21.32 \pm 2.7 \mathrm{~d}$ & $12.34 \pm 0.6 c$ & $19.34 \pm 6.2 d$ \\
\hline \multirow{3}{*}{1200} & Leaf & $145.67 \pm 2.3 \mathrm{a}$ & $56.34 \pm 3.6 \mathrm{a}$ & $26.54 \pm 0.4 \mathrm{a}$ & $66.54 \pm 4.2 \mathrm{a}$ \\
\hline & Stem & $121.21 \pm 7.8 b$ & $39.23 \pm 5.6 b$ & $17.54 \pm 1.3 b$ & $53.21 \pm 1.6 \mathrm{a}$ \\
\hline & Root & $89.34 \pm 2.7 \mathrm{~d}$ & $24.56 \pm 7.3 \mathrm{~d}$ & $13.32 \pm 0.4 \mathrm{c}$ & $21.34 \pm 0.8 \mathrm{~d}$ \\
\hline
\end{tabular}

All analyses are mean \pm standard error of mean (SEM), $N=18$. Means not sharing a common single letter were significantly different at $\mathrm{P} \leq 0.05$. ${ }^{a}$ Data expressed as micromoles of Trolox equivalent per gram dry weight; ${ }^{\mathrm{b}}$ Data expressed as micromoles of $\alpha$-tocopherol equivalent per gram dry weight; ${ }^{\mathrm{c}}$ Data expressed as micromoles of ascorbate equivalent per gram dry weight; ${ }^{\mathrm{d}}$ Data expressed as micromoles of chlorogenic acid equivalent per gram dry weight.

Table 3. The correlationship between total phenolics (TP), total flavonoid (TF), Gluthatione (GSH). Oxidized Gluthatione (GSSH), peroxide radicals (ROO), superoxide radicals $\left(\mathrm{O}_{2}\right)$, hydrogen peroxide $\left(\mathrm{H}_{2} \mathrm{O}_{2}\right)$ hydroxyl radicals $(\mathrm{OH})$ and sucrose $(\mathrm{Suc})$ in the study.

\begin{tabular}{llllllllll}
\hline & $\mathbf{1}$ & $\mathbf{2}$ & $\mathbf{3}$ & $\mathbf{4}$ & $\mathbf{5}$ & $\mathbf{6}$ & $\mathbf{7}$ & $\mathbf{8}$ & $\mathbf{9}$ \\
\hline 1.TP & 1.00 & & & & & & & & \\
2. TF & $0.97 *$ & 1.00 & & & & & & & \\
3. GSH & $0.89 *$ & $0.78 *$ & 1.00 & & & & & & \\
4. GSSH & $0.87 *$ & $0.87 *$ & 0.88 & 1.00 & & & & & \\
$\mathbf{5 . ~ R O O}$ & $0.87 *$ & $0.83 *$ & $0.84 *$ & $0.81 *$ & 1.00 & & & & \\
$\mathbf{6 . ~ O}$ & $0.78 *$ & $0.83 * *$ & $0.86 *$ & $0.89 *$ & $0.85 *$ & 1.00 & & & \\
7. H2 & $0.78 *$ & $0.75 *$ & $0.86 *$ & $0.90 *$ & $0.86 * *$ & $0.81 *$ & 1.00 & & \\
8. OH & $0.76 *$ & $0.90 *$ & $0.89 *$ & $0.87 *$ & $0.83 *$ & $0.92 *$ & $0.79 *$ & 1.00 & \\
9. Suc & $0.88 *$ & $0.76 *$ & $0.87 *$ & $0.92 *$ & $0.86 *$ & $0.76 *$ & $0.81 *$ & $0.83 *$ & 1.00 \\
\hline \multicolumn{7}{c}{$*$ and $* *$ respectively significant at $P \leq 0.05$ or $P \leq 0.01}$. & &
\end{tabular}




\subsection{Glutathione (GSH), Oxidised Glutathione (GSSG) and Ratio of GSH/GSSG}

The GSH, GSGG and GSH/GSSG in L. pumila were influenced by the interaction between $\mathrm{CO}_{2}$ and plant parts ( $\mathrm{P} \leq 0.01$; Table 4). The GSH, GSSG and GSH/GSGG ratio were found to have similar trends as total phenolics and flavonoids accumulation. For GSH the highest accumulation of GSH ( $890.22 \mathrm{nmol}$ gluthathione/g dry weight) was found to be in the leaf at $1,200 \mu \mathrm{mol} / \mathrm{mol} \mathrm{CO}_{2}$, while the lowest (552.2 nmol glutathione/g dry weight) was observed in the root at $400 \mu \mathrm{mol} / \mathrm{mol} \mathrm{CO}_{2}$. In GSSG, leaf-1,200 and root-400 $\mu \mathrm{mol} / \mathrm{mol} \mathrm{CO}_{2}$ recorded 178.65 and $98.34 \mathrm{nmol}$ oxidised glutathione/g dry weight, respectively. For GSH/GSSG ratio the leaf- $1,200 \mu \mathrm{mol} / \mathrm{mol} \mathrm{CO}_{2}$ was statistically significantly higher than leaf-800 and $-400 \mu \mathrm{mol} / \mathrm{mol} \mathrm{CO}_{2}$. However, leaf GSH/GSSG ratio between 400 and $800 \mu \mathrm{mol} / \mathrm{mol} \mathrm{CO} \mathrm{CO}_{2}$ was not statistically significant from each other. $\mathrm{GSH}$ is a tripeptide composed of cysteine, glutamic acid and glycine and is the most abundant nonprotein thiol in the cells. Its active group is the thiol $(-\mathrm{SH})$ of cysteine. The majority of GSH is maintained in the reduced state. The GSH plays an important role in the stabilization of many enzymes. In addition, as antioxidant scavenger it serves as a substrate for dehydroascorbate (DHAsA) reductase and is also directly reactive with free radical including the hydroxyl radical to prevent the inactivation of enzymes by oxidation of an essential thiol group [41]. GSSG consists of two GSH molecules joined by their -SH group into a disulfide bridge and was found to be present in low quantities compared to GSH [25].

Table 4. Gluthathione (GSH), Oxidised Gluthatione (GSHO) and GSH/GSSG ratio in different part of L. pumila under different $\mathrm{CO}_{2}$ concentrations.

\begin{tabular}{|c|c|c|c|c|}
\hline 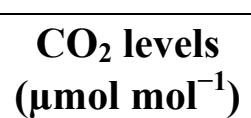 & Plant parts & $\begin{array}{c}\text { GSH } \\
\text { (nmol/g dry wt) }\end{array}$ & $\begin{array}{c}\text { GSSG } \\
\text { (nmol/g dry wt) }\end{array}$ & GSH/GSSG \\
\hline \multirow{3}{*}{400} & Leaf & $744.21 \pm 7.3 b$ & $160.23 \pm 24.1 \mathrm{a}$ & $4.64 \pm 1.7 b$ \\
\hline & Stem & $624.21 \pm 2.1 c$ & $120.23 \pm 1.7 b$ & $4.10 \pm 2.5 c$ \\
\hline & Root & $504.23 \pm 21.2 \mathrm{~d}$ & $98.34 \pm 1.7 \mathrm{c}$ & $3.93 \pm 0.4 d$ \\
\hline \multirow{3}{*}{800} & Leaf & $810.21 \pm 3.4 a$ & $176.34 \pm 2.4 \mathrm{a}$ & $4.89 \pm 0.6 b$ \\
\hline & Stem & $644.21 \pm 2.7 c$ & $132.12 \pm 3.6 b$ & $4.87 \pm 1.7 \mathrm{~d}$ \\
\hline & Root & $505.72 \pm 3.6 \mathrm{~d}$ & $100.23 \pm 2.7 \mathrm{c}$ & $4.94 \pm 2.8 \mathrm{a}$ \\
\hline \multirow{3}{*}{1200} & Leaf & $890.22 \pm 2.4 a$ & $178.65 \pm 2.4 \mathrm{a}$ & $5.85 \pm 2.1 \mathrm{a}$ \\
\hline & Stem & $698.22 \pm 1.8 b$ & $132.14 \pm 3.5 b$ & $4.08 \pm 1.3 c$ \\
\hline & Root & $554.42 \pm 21.3 \mathrm{~d}$ & $99.43 \pm 12.3 c$ & $5.37 \pm 1.4 \mathrm{a}$ \\
\hline
\end{tabular}

All analyses are mean \pm standard error of mean (SEM), $\mathrm{N}=18$. Means not sharing a common single letter were significantly different at $\mathrm{P} \leq 0.05$.

In the present study, we found that $\mathrm{CO}_{2}$ enrichment increased GSH, GSSG and GSH/GSSG ratio. The high GSH and GSH/GSSG ratio are necessary for several physiological functions. Those include activation and inactivation of redox-dependent enzyme systems and regeneration of cellular antioxidant ascorbic acid under oxidative conditions [42,43]. Usually, the increase in GSH and the ratio of GSH/GSSG in enhanced $\mathrm{CO}_{2}$ levels was associated with increase in antioxidant properties [25]. In the current study it was shown that GSH and GSSG have a strong positive relationship with phenolics, flavonoids, $\mathrm{ROO}, \mathrm{O}_{2}, \mathrm{H}_{2} \mathrm{O}_{2}$ and $\mathrm{OH}$. The result showed that the increase in antioxidative properties of L. pumila under elevated $\mathrm{CO}_{2}$ might be due to increase in production of total phenolics, flavonoids, GSH and GSSG activity that can increase the antioxidant of this plant under elevated $\mathrm{CO}_{2}[44,45]$. 


\subsection{Soluble Sugar}

The accumulation and partitioning of soluble sugar were influenced by carbon dioxide enrichment $(P \leq 0.05)$. The accumulation of soluble sugar in different parts of the plant followed a descending order of leaf $>$ root $>$ stem (Table 5). Under ambient conditions, less sucrose was produced in the leaf, stem and root compared to those plants exposed to high $\mathrm{CO}_{2}$ concentration. The present result suggested that enrichment of L. pumila under high $\mathrm{CO}_{2}$ was able to enhance the soluble sugar [37-40]. In recent study by Ibrahim et al. [33] on L. pumila it was observed that the increase in production of total phenolics and flavonoids in L. pumila was due to increase in total non-structural carbohydrates that up-regulated the production of secondary metabolites. The same observation was found in the present study. Data from the correlation Table 3 have shown that soluble sugar had a significant positive relationship with the secondary metabolites (total phenolics and flavonoids) and antioxidant properties. The result implied that the increase in secondary metabolites and antioxidative potential of plant under elevated $\mathrm{CO}_{2}$ might be due to enhancement of production of sucrose. The present finding was in agreement with Guo et al. [46] that found an increase in sucrose content corresponding to the enhanced production of ascorbic acid, glucosinolates, sulforaphane, anthocyanins, total phenolics and increased antioxidative activities in broccoli sprouts. The possitive correlation between carbohydrate content and antioxidative properties in plants were also reported by other researchers [47,48]. The curent results indicate that enhancement of L. pumila with $\mathrm{CO}_{2}$ enrichment can enhance the health promoting effects of this plant due to the increases in total phenolics, flavonoids, GSH and GSGG contents.

Table 5. Accumulation and partitioning of total soluble in different plant parts of L. pumila Blume. under different $\mathrm{CO}_{2}$ levels.

\begin{tabular}{|c|c|c|}
\hline $\mathrm{CO}_{2}$ levels $\left(\mu \mathrm{mol} \mathrm{mol}{ }^{-1}\right)$ & Plant parts & $\mathrm{TSS}_{\text {( }} \mathrm{mg} \mathrm{g}^{-1}$ sucrose dry weight) \\
\hline \multirow{3}{*}{ 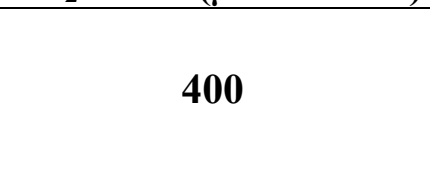 } & Leaf & $16.10 \pm 0.35 c$ \\
\hline & Stem & $14.12 \pm 0.87 \mathrm{c}$ \\
\hline & Root & $9.34 \pm 0.97 \mathrm{e}$ \\
\hline \multirow{3}{*}{800} & Leaf & $21.10 \pm 0.46 b$ \\
\hline & Stem & $16.36 \pm 0.44 c$ \\
\hline & Root & $12.32 \pm 0.56 \mathrm{~d}$ \\
\hline \multirow{3}{*}{1200} & Leaf & $27.96 \pm 0.76 a$ \\
\hline & Stem & $19.45 \pm 0.56 b$ \\
\hline & Root & $14.24 \pm 0.11 \mathrm{c}$ \\
\hline
\end{tabular}

All analyses are mean \pm standard error of mean (SEM), $N=18$. Means not sharing a common single letter were significantly different at $\mathrm{P} \leq 0.05$.

\section{Experimental}

\subsection{Experimental Location, Plant Materials and Treatments}

The experiment was carried out under a growth house complex at Field 2, Faculty of Agriculture Glasshouse Complex, Universiti Putra Malaysia (longitude $101^{\circ} 44^{\prime} \mathrm{N}$ and latitude $2^{\circ} 58^{\prime} \mathrm{S}, 68 \mathrm{~m}$ above sea level) with a mean atmospheric pressure of $1.013 \mathrm{kPa}$. Three-month old L. pumila var alata seedlings were left for a month in a nursery to acclimatize until they were ready for the treatments. 
$\mathrm{CO}_{2}$ enrichment treatment started when the seedlings reached four months of age where plants were exposed to 400, 800 and 1,200 $\mu \mathrm{mol}^{-1} \mathrm{~mol}^{-1} \mathrm{CO}_{2}$. This 2-factorial experiment was arranged in randomized complete block design with $\mathrm{CO}_{2}$ levels and plant parts are the factors and replicated three times.

\subsection{Growth House Microclimate and $\mathrm{CO}_{2}$ Enrichment Treatment}

The seedlings were raised in specially constructed growth houses receiving 12-h photoperiod and average photosynthetic photon flux density of $300 \mu \mathrm{mol} \mathrm{m} \mathrm{m}^{-2} \mathrm{~s}^{-1}$. Day and night temperatures were recorded at $30 \pm 1.0^{\circ} \mathrm{C}$ and $20 \pm 1.5{ }^{\circ} \mathrm{C}$, respectively, and relative humidity at about $70 \%$ to $80 \%$. Vapor pressure deficit ranged from 1.01 to $2.52 \mathrm{kPa}$. Carbon dioxide at $99.8 \%$ purity was supplied from a high-pressure $\mathrm{CO}_{2}$ cylinder and injected through a pressure regulator into fully sealed $2 \mathrm{~m} \times 3 \mathrm{~m}$ growth houses at 2-h daily and applied continuous from 08:00 to 10:00 a.m. [47]. The $\mathrm{CO}_{2}$ concentration at different treatments was measured using Air Sense ${ }^{\text {тм }} \mathrm{CO}_{2}$ sensors designated to each chamber during $\mathrm{CO}_{2}$ exposition period. Plants were watered three to four times a day at 5 min per session to ensure normal growth of plant using drip irrigation with emitter capacity of $2 \mathrm{~L} \mathrm{~h}^{-1}$. The experiment lasted for 15 weeks from the onset of treatment.

\subsection{Extract Preparation}

Leaves, stems and root were freeze-dried to constant weights prior to being used in the extraction process. For antioxidant analysis, the leaves, stems, and roots were powdered and $1 \mathrm{~g}$ of the powder was extracted continuously with methanol $(50 \mathrm{~mL})$. The solution was then swirled for $1 \mathrm{~h}$ at room temperature using an orbital shaker. Extracts were then filtered under suction and stored at $-20{ }^{\circ} \mathrm{C}$ for further use.

\subsection{Total Phenolics and Total Flavonoids Quantification}

The method of extraction and quantification for total phenolics and flavonoids contents followed after Jaafar et al. [50]. An amount of ground tissue sample $(0.1 \mathrm{~g})$ was extracted with $80 \%$ ethanol $\left(10 \mathrm{~mL}\right.$ ) on an orbital shaker for $120 \mathrm{~min}$ at $50{ }^{\circ} \mathrm{C}$. The mixture was subsequently filtered (Whatman ${ }^{\mathrm{TM}}$ No.1), and the filtrate was used for the quantification of total phenolics and total flavonoids. Folin-Ciocalteu reagent (diluted 10-fold) was used to determine the total phenolics content of the leaf samples. Two hundred micro liter of the sample extract was mixed with Follin-Ciocalteau reagent $(1.5 \mathrm{~mL})$ and allowed to stand at $22{ }^{\circ} \mathrm{C}$ for $5 \mathrm{~min}$ before adding $\mathrm{NaNO}_{3}$ solution $(1.5 \mathrm{~mL}, 60 \mathrm{~g} / \mathrm{L})$. After $2 \mathrm{~h}$ at $22{ }^{\circ} \mathrm{C}$, absorbance was measured at $725 \mathrm{~nm}$. The results were expressed as $\mathrm{mg} / \mathrm{g}$ gallic acid equivalent (mg GAE/g dry sample). For total flavonoids determination, sample $(1 \mathrm{~mL})$ was mixed with $\mathrm{NaNO}_{3}(0.3 \mathrm{~mL})$ in a test tube covered with aluminium foil, and left for $5 \mathrm{~min}$. Then $10 \% \mathrm{AlCl}_{3}(0.3 \mathrm{~mL})$ was added followed by addition of $1 \mathrm{M} \mathrm{NaOH}(2 \mathrm{~mL})$ and the absorbance was measured at $510 \mathrm{~nm}$ using rutin as a standard (mg rutin/g dry sample).

\subsection{Measurement of Glutathione (GSH) and Oxidized Glutathione (GSSG)}

GSH and GSSG were assayed using the method described by Castillo and Greppin [51]. Total glutathione were determined by reacting plant extracts $(0.5 \mathrm{~mL})$ with $50 \mathrm{mM} \mathrm{KH}_{2} \mathrm{PO}_{4} / 2.5 \mathrm{mM}$ EDTA 
buffer ( $\mathrm{pH}$ 7.5), 0.6 mM DTNB [5,5-dithiobis-2-nitrobenzoic acid] in $100 \mathrm{mM}$ Tris-HCl, $\mathrm{pH} 8.0$, 1 unit of glutathione reductase (GR, from spinach, EC 1.6.4.2) and $0.5 \mathrm{mM} \mathrm{NADPH}$. GSH was

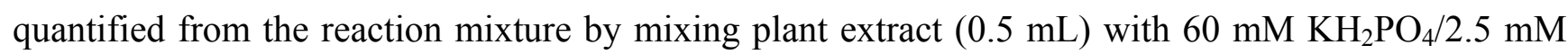
EDTA buffer (pH 7.5), 0.6 mM DTNB [5,5-dithiobis-2-nitrobenzoic acid] in $200 \mathrm{mM}$ Tris-HCl, $\mathrm{pH}$ 8.0. The mixture was incubated at $30{ }^{\circ} \mathrm{C}$ for $15 \mathrm{~min}$, and the reaction was followed as the rate of change in absorbance at $412 \mathrm{~nm}$ using light spectrophotometer (UV-3101P, Labomed Inc, USA) GSSG was determined after removal of GSH from the plant extract.

\subsection{Measurement of Oxygen Radical Absorbance Capacity (ORAC) Assay}

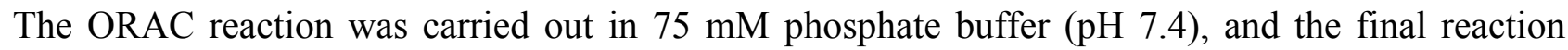
mixture was $200 \mu \mathrm{L}$ as described by Davalos et al. [52]. Antioxidant (20 $\mu \mathrm{L})$ and fluorescein (FL) (120 $\mu \mathrm{L} ; 70 \mathrm{nM}$, final concentration) solutions were placed in the well of the microplate. The mixture was preincubated for $15 \mathrm{~min}$ at $37{ }^{\circ} \mathrm{C}$. 2-Amidinopropane (AAPH) solution $(60 \mu \mathrm{L} ; 12 \mathrm{mM}$ final concentration) was added rapidly using a multichannel pipet. The microplate was immediately placed in the reader and the fluorescence recorded every minute for $80 \mathrm{~min}$. The microplate was automatically shaken prior each reading. A blank (FL + AAPH) using phosphate buffer instead of the antioxidant solution and eight calibration solutions using Trolox (1-8 $\mu \mathrm{M}$, final concentration) as antioxidant were also carried out in each assay. All the reaction mixtures were prepared in duplicate, and at least three independent assays were performed for each sample. The ORAC value refers to the net protection area under the quenching in the presence of an antioxidant. The final results (ORAC value) were calculated and expressed using Trolox equivalents per gram dry weight basis.

\subsection{Measurement of Superoxide Radical $\left(\mathrm{O}_{2}\right)$ Assay}

The assay for $\mathrm{O}_{2}$ was done using the method of Wang et al. [25]. The $\mathrm{O}_{2}$ was generated by xanthine/xanthine-oxidase systems. Nitrite formation from hydroxylammonium chloride was determined at $530 \mathrm{~nm}$ in the spectrophotometer. The reaction mixture contained $1.0 \mathrm{~mL}$ of $65 \mathrm{mM}$ Na-phosphate buffer ( $\mathrm{pH} 7.8$ ), $0.1 \mathrm{~mL}$ of $7.5 \mathrm{mM}$ xanthine, $0.1 \mathrm{~mL}$ of $10 \mathrm{mM}$ hydroxylammonium chloride, $0.1 \mathrm{~mL}$ of fruit extract, and $0.4 \mathrm{~mL}$ of double-distilled $\mathrm{H}_{2} \mathrm{O}$. The reaction was started by addition of $0.3 \mathrm{~mL}$ of xanthine oxidase (containing $60 \mu \mathrm{g}$ of protein). The total reaction volume was $2.0 \mathrm{~mL}$ and incubated at $25{ }^{\circ} \mathrm{C}$ for $20 \mathrm{~min}$. Then, $0.5 \mathrm{~mL}$ was removed from the above reaction mixture, $0.5 \mathrm{~mL}$ of $19 \mathrm{mM}$ sulfanilic acid and $0.5 \mathrm{~mL}$ of $1.0 \%$-naphthylamine were added, and the mixture was shaken for $5 \mathrm{~min}$. After standing at room temperature for $20 \mathrm{~min}$, the optical density of the mixture was determined at $530 \mathrm{~nm}$ against blanks that had been prepared similarly but without plant extract. The final results were expressed as percent inhibition of $\mathrm{O}_{2}$ production in the presence of plant extract. The scavenging capacity of $\alpha$-tocopherol at various concentrations ( 1 to $25 \mu \mathrm{g}$ ) on superoxide radical $\left(\mathrm{O}_{2}\right)$ was measured and used for determining the $\mathrm{O}_{2}$ scavenging capacity of fruit extract. The antioxidant capacity of fruit extract against the $\mathrm{O}_{2}$ value was expressed as $\mu$ mol of $\alpha$-tocopherol equivalent per gram dry weight. 


\section{8. $\mathrm{H}_{2} \mathrm{O}_{2}$ Assay Measurements}

The hydrogen peroxide measurement was based on that described by Petterson et al. [53]. Three hundred milligrams of the youngest, fully expanded plant extract was homogenized in a cold mortar with $5 \mathrm{~mL} \mathrm{5 \%}$ trichloroacetic acid (TCA) containing $0.1 \mathrm{~g}$ activated charcoal and $0.1 \%$ polyvinylpolypyrrolidone (PVPP). The homogenate was filtered and centrifuged at 18,000 $\mathrm{g}$ for $10 \mathrm{~min}$. The supernatant was filtered through a Millipore filter $(0.45 \mathrm{~mm})$ and used for the assay. A $200-\mathrm{mL}$ aliquot was brought to $2 \mathrm{~mL}$ with $100 \mathrm{mM}$ potassium phosphate buffer ( $\mathrm{pH} \mathrm{8.4)}$ ) and $1 \mathrm{~mL}$ of a colorimetric reagent was added. This reagent was prepared daily by mixing $1: 1(\mathrm{v} / \mathrm{v}) 0.6$ potassium titanium oxalate and 0.6 mM 4-2 (2-pyridylazo) resorcinol (disodium salt). After incubating the sample solution at $60{ }^{\circ} \mathrm{C}$ for $45 \mathrm{~min}$, the absorbance was measured at $508 \mathrm{~nm}$. Blanks were made by replacing leaf extract with $5 \%$ TCA. The antioxidant capacity of plant extract against $\mathrm{H}_{2} \mathrm{O}_{2}$ was expressed as $\mu$ mole of ascorbate equivalent per gram dry weight.

\subsection{Measurement of Hydroxyl Radical $(\mathrm{OH} \cdot)$ Assay}

The assay for $\mathrm{OH}$ was done using the methodof Wang et al. [25] with slight modifications. The $\mathrm{OH}$ in aqueous media was generated through the Fenton reaction. The reaction mixture contained 0.24 M K-phosphate buffer ( $\mathrm{pH} 7.4$ ), $1.0 \mathrm{mM}$ salicyclic acid, $0.3 \mathrm{mM} \mathrm{FeSO} / \mathrm{EDTA}(4 \mathrm{mM}), 0.8 \mathrm{mM}$ $\mathrm{H}_{2} \mathrm{O}_{2}$, and $100 \mu \mathrm{L}$ of extracts. The total reaction volume was $5.0 \mathrm{~mL}$ and incubated at $25{ }^{\circ} \mathrm{C}$ for $90 \mathrm{~min}$. Then, $120 \mu \mathrm{L}$ of $6 \mathrm{M} \mathrm{HCl}$ was added, followed by extraction in $4 \mathrm{~mL}$ of chilled ether. Ether was evaporated to dryness in a water bath at $40{ }^{\circ} \mathrm{C}$, and the residue was dissolved in $1 \mathrm{~mL}$ of cold doubledistilled water to which the following was added: $0.5 \mathrm{~mL}$ of $10 \%(\mathrm{w} / \mathrm{v})$ trichloroacetic acid in $0.5 \mathrm{M}$ $\mathrm{HCl}, 1 \mathrm{~mL}$ of $10 \%(\mathrm{w} / \mathrm{v})$ sodium tungstate, $1 \mathrm{~mL}$ of $0.5 \%(\mathrm{w} / \mathrm{v}) \mathrm{NaNO}_{2}$. After standing for $5 \mathrm{~min}$, absorbance at $510 \mathrm{~nm}$ was read immediately after adding $2 \mathrm{~mL}$ of $0.5 \mathrm{M} \mathrm{KOH}$. Relative scavenging efficiency (\% inhibition of hydroxylation) of plant extract was estimated from the difference in absorbance (OD) with and without addition of the plant extract. The scavenging capacity of chlorogenic acid at various concentrations ( 1 to $10 \mu \mathrm{g})$ on hydroxyl radical $(\mathrm{OH})$ was measured and used for determining the $\mathrm{OH}$ scavenging capacity of plant extract. The antioxidant capacity of plant extract against $\mathrm{OH}$ value was expressed as $\mu$ mole of chlorogenic acid equivalent per gram dry weight.

\subsection{Soluble Carbohydrates (Sucrose)}

Soluble carbohydrates were measured spectrophotometrically using the method described by Edward [54]. Samples (0.5 g) were placed in $15 \mathrm{~mL}$ conical tubes. Then distilled water $(10 \mathrm{~mL})$ was added and the mixture was then vortexed and incubated for $10 \mathrm{~min}$. Anthrone reagent was prepared using anthrone $(0.1 \mathrm{~g})$ that was dissolved in $95 \%$ sulphuric acid $(50 \mathrm{~mL})$. Sucrose was used as a standard stock solution to prepare a standard curve for the quantification of sucrose in the sample. The mixed sample of ground dry sample and distilled water was centrifuged at a speed of 3,400 rpm for $10 \mathrm{~min}$ and then filtered to get the supernatant. To an aliquot $(4 \mathrm{~mL})$ of the sample was added anthrone reagent $(8 \mathrm{~mL})$ and the mixture was placed in a waterbath set at $100{ }^{\circ} \mathrm{C}$ for $5 \mathrm{~min}$ before the sample was measured at absorbance $620 \mathrm{~nm}$ using UV160U spectrophotometer (Shimadzu, Japan). The soluble sugar in the sample was expresses as mg sucrose per gram dry sample. 


\subsection{Statistical Analysis}

Data were analyzed using analysis of variance by SAS version 17. Mean separation test between treatments was performed using Duncan multiple range test and standard error of differences between means was calculated with the assumption that data were normally distributed and equally replicated.

\section{Conclusions}

The application of higher than ambient $\mathrm{CO}_{2}$ levels seems able to enhance the production of total phenolics, flavonoids, GSH and GSHH of L. pumila. The increase in these compounds in the plant extract might be attributed to the enhanced antioxidative properties of $L$. pumila as indicated by the high oxygen radical absorbance activity against $\mathrm{ROO}, \mathrm{O}_{2}, \mathrm{H}_{2} \mathrm{O}_{2}$, and $\mathrm{OH}$ in the plant parts. The study also showed the increase in antioxidative properties of $L$. pumila under elevated $\mathrm{CO}_{2}$ might be due to increase in the production of sucrose levels that might enhance the phytomedicinal properties of the plants.

\section{Acknowledgements}

The authors are grateful to the Ministry of Higher Education Malaysia and the Research Management Centre of Universiti Putra Malaysia for financing this work under the Research University Grant Scheme Number 91007. Appreciation is also due for the Ministry of Agriculture and Agro-based Industry Malaysia for partially sponsoring the work under the Science Fund Scheme Vote Number 5450487.

\section{References}

1. Lundeårdh, H. Der Kreislauf der Kohlensaure in der Natur; Fischer, G., Ed.; Verlag KG: Jena, Germany, 1924.

2. Bailey, B.J. Greenhouse climate control: New challenges. Acta Hort. 1995, 399, 13-23.

3. Porter, M.A.; Grodzinski, B. $\mathrm{CO}_{2}$ enrichment of protected crops. Hortic. Res. 1985, 7, 345-398.

4. Chen, K.; Hu, G.; Lenz, F. Effects of $\mathrm{CO}_{2}$ concentration on strawberry. VI. Fruit yield and quality. Angew Bot. 1997, 71, 195-200.

5. Brevoort, P. The blooming United State botanical market: A new overview. Herbalgram 1998, 44, 33-46.

6. Jaafar, H.Z.E. Carbon dioxide enrichment technology for improved productivity under controlled environment system in the tropics. Acta Hort. 2006, 742, 353-363.

7. Byers, T.; Guerrero, N. Epidemilogic evidence for vitamin $\mathrm{C}$ and vitamin $\mathrm{E}$ in cancer prevention. Am. J. Clin. Nutr. 1995, 62, 1385-1392.

8. Namiki, M. Antioxidant/antimutagens in food, critical reviews of food science and nutrition. Food Sci. Nutr. 1990, 29, 273-300.

9. Heijnen, C.G.; Haenen, G.R.; Vanacker, F.A.; Vijgh, W.J.; Bast, A. Flavonoids as peroxynitrite scavengers:the role of the hydroxyl groups. Toxicol. Vitro 2001, 15, 3-6.

10. Chun, O.K.; Kim, D.O.; Lee, C.Y. Superoxide radical scavenging activity of the major polyphenols in fresh plums. J. Agric. Food Chem. 2003, 51, 8067-8072. 
11. Chan, E.W.C.; Lim, Y.Y.; Wong, L.F.; Lianto, F.S.; Wong, S.K.; Lim, K.K.; Joe, C.E.; Lim, T.Y. Antioxidant and tyrosinase inhibition properties of leaves and rhizomes of ginger species. Food Chem. 2008, 109, 477-483.

12. Harborne, J.B.; Williams, C.A. Advances in flavonoid research science. Phytochemistry 2000, 55, 481-504.

13. Chen, G. Effect of low fat and/or high fruit and vegetable diets on plasma level of 8-isoprostaneF2alpha in nutrition and breast health study. Nutr. Cancer 2004, 50,155-160.

14. Sung-Jin, P.; Hoon, M.; Young-Youn, K.; Jun-Young, P.; Jun-Woo, P.; Myung-Jin, K.; Soon-Min, H. Anticancer effects of genistein, green tea catechins, and cordycepin on oral squamous cell carcinoma. J. Korean Oral Maxillofac. Surg. 2008, 34, 1-10.

15. Booker, F.L. Influence of carbon dioxide enrichment, ozone and nitrogen fertilization on cotton (Gossypium hirsutum L.) leaf and root composition. Plant Cell Environ. 2000, 23, 573-583.

16. Idso, S.B.; Kimball, B.A.; Pettit, G.R., III.; Garner, L.C.; Pettit, G.R.; Backhaus, R.A. Effects of atmospheric $\mathrm{CO}_{2}$ enrichment on the growth and development of Hymenocallis littoralis (Amaryllidaceae) and the concentrations of several antineoplastic and antiviral constituents of its bulbs. Am. J. Bot. 2000, 87, 769-773.

17. Pettit, G.R.; Gaddamidi, V.; Herald, D.L.; Singh, S.B.; Cragg, G.M.; Schmidt, J.M.; Boettner, F.E.; Williams, M.; Sagawa, Y. Antineoplastic agents, 120. Pancratiumlittorale. J. Nat. Prod. 1986, 49, 995-1002.

18. Barbale, D. The influence of the carbon dioxide on the yield and quality of cucumber and tomato in the coveredareas. Augsne un Raza (Riga) 1970, 16, 66-73.

19. Madsen, E. The influence of $\mathrm{CO}_{2}$-concentration on the content of ascorbic acid in tomato leaves. Ugeskr. Agron. 1971, 116, 592-594.

20. Madsen, E. Effect of $\mathrm{CO}_{2}$ environment on growth, development, fruit production and fruit quality of tomato from a physiological viewpoint. In Phytotronics in Agricultural and Horticultural Research; Chouard, P., de Bilderling, N., Eds.; Bordas: Paris, France, 1975; pp. 318-330.

21. Tajiri, T. Improvement of bean sprouts production by intermittent treatment with carbon dioxide. Nippon Shokuhin Kogyo Gakkaishi 1985, 32, 159-169.

22. Schwanz, P.; Kimball, B.A.; Idso, S.B.; Hendrix, D.L.; Polle, A. Antioxidants in sun and shade leaves of sourvorange trees (Citrus aurantium) after long-term acclimation to elevated $\mathrm{CO}_{2}$. J. Exp. Bot. 1996, 47, 1941-1950.

23. Rao, M.V.; Hale, B.A.; Ormrod, D.P. Amelioration ofozone-induced oxidative damage in wheat plants grown under high carbon dioxide. Role of antioxidant enzymes. Plant Physiol. 1995, 109, 421-432.

24. Foyer, C.H.; Descourvieres, P.; Kunert, K.J. Protection against oxygen radicals: An important defense mechanism studied in transgenic plants. Plant Cell Environ. 1994, 17, 507-523.

25. Wang, Y.S.H.; Bunce, A.J.; Maas, L.J. Elevated carbon dioxide increases contents of antioxidant compounds in field-grown strawberries. J. Agric. Food Chem. 2003, 51, 4315-4320.

26. Polle, A.; Eiblmeier, M.; Sheppard, L.; Murray, M. Responses of antioxidative enzymes to elevated $\mathrm{CO}_{2}$ in leaves of beech (Fagus syl6atica L.) seedlings grown under a range of nutrient regimes. Plant Cell Environ. 1997, 20, 1317-1321. 
27. Schwanz, P.; Polle, A. Antioxidative systems, pigment and protein contents in leaves of adult Mediterranean oak species (Quercus pubescens and Q. ilex) with lifetime exposure to elevated $\mathrm{CO}_{2}$. New Phytol. 1998, 140, 411-423.

28. Pérez-López, U.; Robredo, A.; Lacuesta, M.; Sgherri, C.; Muñoz-Rueda, A.; Navari-Izzo, F.; Mena-Petite, A. The oxidative stress caused by salinity in two barley cultivars is mitigated by elevated $\mathrm{CO}_{2}$. Physiol. Plantarum 2009, 135, 29-42.

29. Pérez- López, U.; Robredo, A.; Lacuesta, M.; Sgherri, C.; Mena, A.; Navari, F.; Muñoz, A. Lipoic acid and redox status in barley plants subjected to salinity and elevated $\mathrm{CO}_{2}$. Physiol. Plantarum 2010, 139, 256-268.

30. Norhaiza, M.; Maziah, M.; Hakiman, M. Antioxidative properties of leaf extracts of popular Malaysian herb, Labisia pumila. J. Med. Plant Res. 2009, 3, 217-223.

31. Jaafar, H.Z.E.; Mohamed, H.N.B.; Rahmat, A. Accumulation and partitioning of total phenols in two varieties of Labisia pumila Benth. under manipulation of greenhouse irradiance. Acta Hort. 2008, 797, 387-392.

32. Jamia, A.J.; Ibrahim, J.; Khairana, H.; Juriyati, H. Perkembangan Penyelidikan dan Pembangunan Kacip Fatimah; New Dimension in Complementary Health Care: Kuala Lumpur, Malaysia, 2004; pp. 13-19.

33. Ibrahim, M.H.; Jaafar, H.Z.E.; Rahmat, A.; Zaharah, A.R. The relationship between phenolics and flavonoid production with total non structural carbohydrate and photosynthetic rate in Labisia pumila Benth. Under High $\mathrm{CO}_{2}$ and nitrogen fertilization. Molecules 2011 16, 162-174.

34. Karimi, E.; Jaafar, H.Z.E.; Ahmad, S. Phenolics and flavonoids profiling and antioxidant activity of three varieties of Malaysian indigenous medicinal herb Labisia pumila Benth. J. Med. Plant Res. 2011, 5, 1200-1206.

35. Ghasemzadeh, A.; Jaafar, H.Z.E.; Rahmat, A.; Wahab, P.E.M.; Halim, M.R.A. Effect of different light intensities on total phenolics and flavonoids synthesis and anti-oxidant activities in young ginger varieties (Zingiber officinale Roscoe). Int. J. Mol. Sci. 2010, 11, 3885-3897.

36. Malikov, V.M.; Yuledashev, M.P. Phenolic compounds of plants of the Scutellaria L. genus: Distribution, structure, and properties. Chem. Nat. Compd. 2002, 38, 358-406.

37. Stutte, G.W.; Eraso, I. Carbon dioxide enrichment enhances growth and flavonoid content of two Scutellaria species. J. Am. Soc. Hort. Sci. 2008, 133, 631-638.

38. Caldwell, C.R.; Britz, S.J.; Mirecki, R.M. Effect of temperature, elevated carbon dioxide, and drought during seed development on the isoflavone content of dwarf soybean (Glycine max (L.) Merrill grown in controlled environments. J. Agric. Food Chem. 2005, 53, 1125-1129.

39. Geraets, L.; Haegens, A.; Brauers, K.; Haydock, J.A.; Vernooy, J.H.; Wouters, E.F.; Bast, A.; Hageman, G.J. Inhibition of LPS-induced pulmonary inflammation by specific flavonoids. Biochem. Biophys. Res. Commun. 2009, 382, 598-603.

40. Tolonen, M.; Taipale, M.; Viander, B.; Pihlava, J.M.; Korhonen, H.; Ryhänen, E.L. Plant-derived biomolecules in fermented cabbage. J. Agric. Food. Chem. 2002, 50, 6798-6803.

41. Dalton, D.A.; Russell, S.A.; Hanus, F.J.; Pascoe, G.A.; Evans, H.J. Enzymatic reactions of ascorbate and glutathione that prevent peroxide damage in soybean root nodules. Proc. Natl. Acad. Sci. USA 1986, 83, 3811-3813. 
42. Foyer, C.H. Ascorbic acid. In Antioxidants in Higher Plants; Alscher, R.G., Hess, J.L., Eds.; CRC: Boca Raton, FL, USA, 1993; pp. 31-48, 51-52.

43. Ziegler, D.M. Role of reversible oxidation reduction of enzyme thiols-disulfides in metabolic regulation. Annu. Rev. Biochem. 1985, 54, 305-329.

44. Lewis, N.G. Plant phenolics. In Antioxidants in Higher Plants; Alscher, R.G., Hess, J.L., Eds.; CRC: Boca Raton, FL, USA, 1993; pp.135-160.

45. Larson, R.A. The antioxidants of higher plants. Phytochemistry 1988, 27, 969-978.

46. Guo, R.; Yuan, G.; Wang, Q. Effects of sucrose and mannitol accumulation of health promoting component and activity of metabolic enzyme in brocolli sprout. Scien. Hort. 2011, 128, 159-165.

47. Kubula, J.; Sriamoopunns, S.; Meeso, N. Phytochemical, vitamin C and sugar content of thai wild fruits. Food Chem. 2011, 126, 972-981.

48. Veenashi, B.R.; Muralikrishna, G. In vitro antioxidant activity of xylo-oligosharides derrived from cereal and millet brans-a competitive study. Food Chem. 2011, 126, 1475-1481.

49. Jaafar, H.Z.E. Carbon dioxide enrichment technology for improved productivity under controlled environment system in the tropics. Acta Hort. 2006, 742, 353-363.

50. Jaafar, H.Z.E.; Ibrahim, M.H.; Por, L.S. Effects of $\mathrm{CO}_{2}$ enrichment on accumulation of total phenols, flavonoid and chlorophyll content in two varieties of Labisia pumila Benth. exposed to different shade levels. Proceedings of International Conference on Balanced Nutrient Management for Tropical Agriculture, Kuantan, Pahang, Malaysia, 15-22 February 2010; UPM: Kuala Lumpur, Malaysia, 2010; pp. 112-114.

51. Castillo, F.J.; Greppin, H. Extracellular ascorbic acid and enzyme activities related to ascorbic acid metabolism in Sedum Album L. leaves after ozone exposure. Env. Exp. Bot. 1988, 28, 232-233.

52. Dávalos, A.; Gomez-Cordoves, C.; Bartolomé, B. Extending applicability of the oxygen radical absorbance capacity (ORAC- Fluorescein) assay. J. Agric. Food Chem. 2004, 52, 48-54.

53. Patterson, B.D.; MacRae, E.A.; Ferguson, I.B. Estimation of hydrogen peroxide in plant extracts using titanium (IV). Anal. Biochem. 1984, 139, 487-492.

54. Edward, J.N. The effects of trinexapac ethyl and three nitrogen sources on creeping bentgrass (Agrostis stolonnifera) grown under three light environments. Master Thesis, The Ohio State University: Columbus, OH, USA, 2008.

Sample Availability: Not available.

(C) 2011 by the authors; licensee MDPI, Basel, Switzerland. This article is an open access article distributed under the terms and conditions of the Creative Commons Attribution license (http://creativecommons.org/licenses/by/3.0/). 